\title{
THE INFLUENCE OF AGRIBUSINESS SUBSYSTEM ON BEEF CATTLE FATTENING FARM'S PROFIT IN CENTRAL JAVA
}

\author{
E. Prasetyo ${ }^{1}$, Sunarso ${ }^{1}$, P. B. Santosa ${ }^{2}$ and E. Rianto ${ }^{1}$ \\ ${ }^{1}$ Faculty of Animal Agriculture, Diponegoro University, \\ Tembalang Campus, Semarang 50275 - Indonesia \\ ${ }^{2}$ Faculty of Economics and Business, Diponegoro University, \\ Tembalang Campus, Semarang 50275 - Indonesia \\ Corresponding E-mail: edyprsty@yahoo.com
}

Received April 09, 2012; Accepted May 22, 2012

\begin{abstract}
ABSTRAK
Penelitian ini bertujuan untuk : (i) Mengetahui penerapan subsistem dan perencanaan agribisnis; (ii) Menghitung nilai pendapatan; dan (iii) Menganalisis pengaruh penerapan subsistem dan perencanaan agribisnis terhadap pendapatan usaha penggemukan sapi potong pada peternak rakyat. Penelitian ini menggunakan metode survai dan sebagai unit elementer adalah peternak sapi potong rakyat (pola penggemukan). Penentuan sampel menggunakan Purposive Quota Sampling Method pada 112 responden yang tersebar di 5 wilayah kabupaten (Blora, Rembang, Grobogan, Wonogiri, dan Boyolali). Data dikumpulkan dari sumber primer dan didukung data dari sumber sekunder. Analisis data menggunakan metoda statistik deskriptif kuantitatif dan statistik inferensial, yang meliputi scoring analysis, analisis pendapatan, dan multiple linear regression analysis. Hasil penelitian menunjukkan bahwa: (i) Penerapan subsistem agribisnis (meliputi subsistem praproduksi, pemasaran, dan jasa penunjang agribisnis) serta perencanaan agribisnis pada tingkat peternak dalam katagori kurang, sedangkan subsistem usaha ternak dalam katagori cukup; (ii) Skala usaha rata-rata tiap peternak sebanyak 2,95 ekor dengan tingkat pendapatan sebesar Rp 1044.719,- per-periode penggemukan selama 6,68 bulan (setara dengan Rp 156.395,- per-bulan); (iii) Secara serempak subsistem dan perencanaan agribisnis berpengaruh nyata terhadap pendapatan peternak, namun secara parsial hanya subsistem praproduksi dan jasa penunjang agribisnis yang berpengaruh nyata terhadap pendapatan peternak.
\end{abstract}

Kata kunci : pendapatan, penggemukan, sapi potong rakyat, subsistem agribisnis

\begin{abstract}
This study was aimed : (i) to know the subsystem implementation and agribusiness planning in beef cattle fattening; (ii) to count the profit of beef cattle farming; (iii) to analyze the effect of agribusiness subsystem implementation and agribusiness planning to beef cattle fattening profit. This study was carried out using survey method and the elementary units were feedlot farmers. The sample was determined by Purposive Quota Sampling Method on 112 respondents spread across five regencies, namely Blora, Rembang, Grobogan, Wonogiri, and Boyolali. Data were collected from primary and secondary sources. The data analysis used quantitative descriptive and inferential statistics method, which include scoring, financial, and multiple linear regression analysis. The results showed that : (i) the implementation of agribusiness subsystem (including preproduction subsystem, marketing, and agribusiness support services) and agribusiness planning were not so good category, while the cattle farming subsystem was moderate category; (ii) the average of farming scale in each feedlot farmer was 2.95 head of cattle with the profit rate was IDR 1,044,719 per fattening period during 6.68 months (equivalent to IDR 156,395 per month); (iii) agribusiness subsystem and agribusiness planning had significant impact on feedlot farmer profit simultaneously, but preproduction subsystem and the agribusiness support services subsystem partially had a significant impact on feedlot farmer profit.

Keywords: agribusiness subsystems, beef cattle, fattening, profit
\end{abstract}

\section{INTRODUCTION}

Recently, the existence of animal husbandry is still a strategic subsector for supporting Central Java economy. It is an occupation for most 
people, especially in rural community. The production of livestock sub-sector has not been able to meet the food needs of animal origin (except eggs). Contribution of livestock sub sector to total gross regional domestic product in Central Java : (i) based on valid price on agriculture sector in 2007 amount to IDR 8,876,197.26 million (13.91\%); (ii) based on constant price in 2000 amount to IDR 4,033,969.27 million (12.66\%). In the agriculture sector, contribution of gross regional domestic product livestock sub sector is the second largest in order to farm food crops sub sector (Jawa Tengah dalam Angka, 2010).

Central Java has the second largest beef cattle population in Indonesia, after East Java. Beef cattle is one of meat-producing resources that has high economic value, and has important role in public life. Beef cattle agribusiness have very good prospect, because of demand of meet continuous to increase equally with population growth and national economic development. However, beef imports tend to be increased in recent decades (Badan Litbang Pertanian, 2007). During 2005-2009, Indonesia was still import 40 percent of total beef-needs and it reaches 322.1 thousands tons in 2009.

Beef cattle farming have not been profit oriented. This condition is caused by any problems faced by feedlot farmer, especially farming capital, education, and knowledge about implementation of agribusiness system and planning. Agribusiness systems that approach to agricultural development are a complete system which can be used by feedlotter to conduct their business efficiently.

The aims of this study were: (i) to evaluate the implementation level of agribusiness subsystem (include preproduction subsystem, farming subsystem, marketing subsystem, agribusiness supporting service subsystem), and agribusiness planning of beef cattle fattening; (ii) to calculate the profit of beef cattle fattening; and (iii) to analyze the effect of agribusiness subsystem and agribusiness planning implementation to the profit of beef cattle fattening.

\section{MATERIALS AND METHODS}

The study was conducted in Blora, Rembang, Grobogan, Wonogiri, and Boyolali region on beef cattle farming, and elementary units were the feedlot farmers in that regions. The study results were expected to represent real condition, so it was needed to collect empirical data from primary and secondary sources. Then, data processing, data analyzing, and discussion could be conducted. This study was conducted in April - November 2010.

Samples used for study were determined using Purposive Quota Sampling method (Daniel, 2002). Purposive was applied for determining study location based on 5 regions with the largest population of beef cattle in Central Java. Quota was applied for determining the number of samples that was collected as elementary units in each region, without counting population as sampling frame. The number of samples selected as respondents were 25 feedlot farmers in each region, except in Blora Region only 22 and Rembang Region 15 feedlot farmers. Total of samples was 112 respondents of the 5 regions.

The data were analyzed using quantitative descriptive method and inferential statistics, including scoring analysis, profit analysis, and multiple linear regression models. Each study objectives were analyzed using the methods below:

1. Scoring analysis was used for analyzing subsystem implementation and agribusiness planning used. The unit used was score, and then it was classified in very good ( score $=5)$, good $($ score $=4)$, moderate $($ score $=3)$, not so good $($ score $=2)$, and not $\operatorname{good}($ score $=1)$ category.

2. The profit of beef cattle farming was analyzed using farming profit analysis. To detect profit farm value, beforehand it was important to know physical values and price per-unit from input factor also output factor, then calculated to production cost and the revenue (Prasetyo et al., 2005). Mathematical formula used was:

$\pi=\mathrm{TR}-\mathrm{TC}$

$\mathrm{TR}=\mathrm{Qi} \times \mathrm{Pqi}$

$\mathrm{TC}=\mathrm{TVC}+\mathrm{TFC}$

Where :

$\pi=$ Profit of beef cattle fattening farm (IDR)

$\mathrm{TR}=$ Total Revenue (IDR)

$\mathrm{Qi}=$ Quantity of product $(\mathrm{kg})$

Pqi $=$ Price of product per kilogram (IDR)

$\mathrm{TC}=$ Total cost (IDR)

$\mathrm{TVC}=$ Total Variable cost (IDR)

TFC $=$ Total Fixed cost (IDR)

3. The effects of subsystem implementation 
Table 1. Performance of Beef Cattle Farming i Five Regencies

\begin{tabular}{lrrrrrr}
\hline \multirow{2}{*}{ Identify } & \multicolumn{7}{c}{ Regency } \\
\cline { 2 - 7 } & Blora & Rembang & Grobogan & Wonogiri & Boyolali & Average \\
\hline Number of cattle (head) & 6.60 & 3.33 & 1.28 & 4.44 & 1.80 & 3.49 \\
Time for fatt (month) & 8.60 & 5.22 & 11.34 & 3.04 & 6.13 & 6.87 \\
Early weight (kg/head) & 320.41 & 279.60 & 287.32 & 260.46 & 264.44 & 282.45 \\
Final weight (kg/head) & 566.86 & 389.84 & 482.25 & 283.88 & 336.87 & 411.89 \\
Weight gain (kg/head) & 242.32 & 110.24 & 194.94 & 23.42 & 71.53 & 129.35 \\
Technology : & & & & & & \\
a. Traditional (\%) & 44.00 & 0 & 80.00 & 68.00 & 64.00 & 51.20 \\
b. Semi intensive (\%) & 36.00 & 80.00 & 20.00 & 28.00 & 36.00 & 40.00 \\
c. Intensive (\%) & 20.00 & 20.00 & 0 & 4.00 & 0 & 8.80 \\
Race of cattle : & & & & & & \\
a. Ongole crossbred (\%) & 20.00 & 40.00 & 4.00 & 12.00 & 68.00 & 28.80 \\
b. Simmental (\%) & 12.00 & 20.00 & 48.00 & 84.00 & 28.00 & 38.40 \\
c. Limousine (\%) & 64.00 & 26.67 & 32.00 & 4.00 & 0 & 25.33 \\
d. Brahman (\%) & 4.00 & 13.33 & 16.00 & 0 & 4.00 & 7.47 \\
\hline
\end{tabular}

and agribusiness planning to profit rate were analyzed using multiple linear regression model with mathematical formula was according to Supranto (1984): $\pi=\alpha+\beta_{1} X_{1}+\beta_{2} X_{2}+\beta_{3} X_{3}+\beta_{4} X_{4}+\beta_{5} X_{5}+E$

Where :

$\pi=$ Profit of beef cattle fattening farm (IDR).

$\alpha=$ Constant (intercept).

$\beta \mathrm{i}=$ Regression coeficient for each agribusiness subsystem.

$\mathrm{X}_{1}=$ Implementation of preproduction subsystem (score).

$\mathrm{X}_{2}=$ Implementation of farming

$\mathrm{X}_{3}=$ Implementation of product marketing subsystem (score)

$X_{4}=$ Acces of agribusiness supporting

$\mathrm{X}_{5} \quad$ service (score)

$\mathrm{X}_{5}=$ Agribusiness planning (score)

$\mathrm{E}=$ Disturbance of term.

\section{RESULTS AND DISCUSSION}

The five regions that have the largest beef cattle population in Central Java are Blora, Rembang, Grobogan, Wonogiri, and Boyolali region. The farming system of beef cattle fattening are still largely traditional. The rules of economic principles have not been applied optimally in traditional system, because beef cattle farming are still positioned as sideline business by farmer. In many agricultural production systems an animal component is included, in addition to the plant component (Van de Ven et al., 2003). Meanwhile the educational background of most feedlot farmer is elementary school. According to Soeharjo and Patong (1973), the level of education affects the emergence of new innovations.

The average scale of beef cattle farming was 2.95 head of cattle per feedlot farmer, the period for fattening was 6.68 months per production cycle, and beef cattle's weight gain was 0.635 $\mathrm{kg} / \mathrm{h}$ ead/day. These conditions reflected that beef cattle farming have not been commercially cultivated. Performance of beef cattle farming is presented in Table 1.

System of implementation and agribusiness planning of beef cattle farming were in not so good category in each region (average score $=$ 2.07). Based on implementation of agribusiness 
Table 2. System Implementation and Planning Agribusiness (Score) in Five Regencies

\begin{tabular}{lrrrrrr}
\hline \multirow{2}{*}{\multicolumn{1}{c}{ Explanation }} & \multicolumn{7}{c}{ Regency } \\
\cline { 2 - 7 } & Blora & Rembang & Grobogan & Wonogiri & Boyolali & Average \\
\hline Preproduction & 22.45 & 17.49 & 13.61 & 26.89 & 28.55 & 21.80 \\
Farming subsystem & 23.84 & 24.93 & 17.40 & 28.76 & 22.56 & 23.50 \\
Marketing product & 11.16 & 8.00 & 9.56 & 7.12 & 14.04 & 9.98 \\
Supporting services & 16.48 & 8.93 & 9.44 & 12.00 & 16.68 & 12.58 \\
Agribusiness plan. & 16.56 & 20.87 & 11.80 & 17.76 & 17.40 & 16.88 \\
\hline Total (41 component) & 90.49 & 80.22 & 61.82 & 92.53 & 99.23 & 84.74 \\
Average/component & 2.21 & 1.96 & 1.51 & 2.26 & 2.42 & 2.07 \\
\hline
\end{tabular}

Table 3. System Implementation and Planning Agribusiness by Category

\begin{tabular}{lcccc}
\hline \multicolumn{1}{c}{ Explanation } & Component Number & Score Number & Score Average & Category \\
\hline Preproduction & 12 & 21.80 & 1.82 & not so good \\
Farming Subsystem & 9 & 23.50 & 2.61 & moderate \\
Marketing Product & 6 & 9.98 & 1.66 & not so good \\
Supporting Services & 7 & 12.58 & 1.80 & not so good \\
Agribusiness Planning & 7 & 16.88 & 2.41 & not so good \\
\hline
\end{tabular}

$\begin{array}{ll}\text { Score } 5=\text { very good } & \text { Score } 2=\text { not so good } \\ \text { Score } 4=\text { good } & \text { Score } 1=\text { bad } \\ \text { Score } 3=\text { moderate } & \end{array}$

subsystem, these all were in not so good category, except farming subsystem was in moderate category. Based on the score, the order from the largest to the smaller were Boyolali, Wonogiri, Blora, Rembang, and Grobogan region. The implementation of agribusiness system and planning presented on Table 2 and 3.

Implementation system and agribusiness planning were not optimally applied due to several external and internal factors in the feedlot farmer. These factors were : (i) The number, time availability, and quality of producing facilities (especially feeder cattle and feed) generally in less favorable; (ii) The increasing rate of farming product price trend to be smaller than the increasing rate of farming facilities price; (iii) The availability of agribusiness supporting services, especially financial institutions and human resource development institutions, have not been well used; (iv) The activities of agribusiness planning have not been done properly. Besides that, farming activity is still considered as sideline business.

The profit of beef cattle fattening farming was IDR 1,044,719 with average farm scale 2.95 head of cattle. If the average time required for fattening beef cattle was 6.68 months, so the value of monthly income equivalent to IDR 156,395 . This value was smaller than the provincial minimum wage of Central Java in 2010 (IDR $675,000)$. Profit is the main purpose of a business. It can be obtained when the amount of business income greater than the amount of expenditures. A business can be indicated feasible to be developed if its profit is always increased. According to Ramsey et al. (2005), productivity measures 
Table 4. Production Cost, Revenue, and Profit Average of Beef Cattle Farming

\begin{tabular}{lrrrrrr}
\hline Regencies & $\begin{array}{c}\text { Cattle } \\
\text { (head) }\end{array}$ & $\begin{array}{c}\text { Fattening } \\
\text { Time } \\
\text { (month) }\end{array}$ & $\begin{array}{c}\text { Fixed Cost } \\
\text { (IDR) }\end{array}$ & $\begin{array}{c}\text { Var. Cost } \\
\text { (IDR) }\end{array}$ & $\begin{array}{c}\text { Revenue } \\
\text { (IDR) }\end{array}$ & Profit (IDR) \\
\hline Blora & 3.91 & 7.68 & 3010126 & 36744273 & 44974273 & 5219874 \\
Rembang & 3.33 & 5.22 & 217622 & 28037254 & 28693067 & 438191 \\
Grobogan & 1.28 & 11.34 & 1469104 & 10491710 & 12889200 & 928386 \\
Wonogiri & 4.44 & 3.04 & 1282391 & 43684048 & 43416000 & -1550439 \\
Boyolali & 1.80 & 6.13 & 222805 & 14343560 & 13040350 & 187583 \\
\hline Total & 14.76 & 33.41 & 6202048 & 72729965 & 143012890 & 5223595 \\
Average & 2.95 & 6.68 & 1240410 & 14545993 & 28602578 & 1044719 \\
\hline
\end{tabular}

affected costs, over all production, and profits. In order to make favorable economic outlook of fattening pattern beef cattle farming, some efforts need to be done, namely: (i) To increase the quantity of farming products. Increasing the quantity of the results can be done by applying the agribusiness system (especially the farming subsystem) properly. Lestari et al. (2011) stated that the productivity of beef cattle production can be measured by the average daily gain. (ii) To Increase the price of the product. Increasing product prices can be done by applying the agribusiness system (especially the marketing subsystem) properly. (iii) To reduce the production costs (especially variable costs) as efficiently as possible, without sacrificing quality of input factor used in the production process.

Production costs, revenues and profit of beef cattle fattening are presented in Table 4. The effects of agribusiness system and agribusiness planning to profit of beef cattle fattening was obtained as follows:

$\mathrm{Y}=-13843625.24-535372.74 \mathrm{X}_{1}+273910.05 \mathrm{X}_{2}$ $+416197.20 X_{3}+1070037.97 X_{4}+287437.06 X_{5}$

Beef cattle farming subsystem $\left(\mathrm{X}_{2}\right)$, the marketing of livestock $\left(\mathrm{X}_{3}\right)$, agribusiness support services $\left(\mathrm{X}_{4}\right)$, and agribusiness planning $\left(\mathrm{X}_{5}\right)$ had positive impacts on the profit of beef cattle fattening (Y), whereas the preproduction subsystems $\left(\mathrm{X}_{1}\right)$ had negative impacts on the profit of beef cattle fattening $(\mathrm{Y})$.

$F$ test reflected agribusiness subsystem and agribusiness planning variables significantly influenced the profit of fattening beef cattle simultaneously $(\mathrm{P}<0.05)$. T test reflected only two of the five independent variables significantly influenced the dependent variable, namely preproduction subsystems and agribusiness support services subsystem $(\mathrm{P}<0.05)$. Meanwhile, the beef cattle farming subsystems, product marketing and agribusiness planning did not significantly influence the profit of beef cattle fattening $(\mathrm{P}>0.05)$.

Preproduction subsystem had significant negative effects on beef cattle farming profit. These conditions imply that preproduction activities in the reality were not efficient, especially the provision of feeder cattle that was too expensive and poor quality. This can be reflected by the average of body weight gain of $0.635 \mathrm{~kg}$ per day. According Sudarmono and Sugeng (2008), the success of beef cattle fattening business is largely determined by the condition of calves as a basic material. Productivity of livestock is the result of genetic and environmental influences (Dalton, 1987). Legates et al. (1979) stated that the performance of an animal is affected by genetic and accumulation of environmental factors experienced by the animal since it growth until measured or observed. Hardjosubroto (1994) stated that genetic factors determine the ability of an animal, and environmental factors may give opportunity to show its ability. Meanwhile, it is necessary to get more thoroughly and carefully efforts for the procurement of feeder cattle.

Agribusiness supporting services subsystem had positive effect on beef cattle farming profit significantly. Therefore the activities relating to access to agribusiness supporting services needed to be improved better, especially access to 
livestock markets, venture capital institutions, animal health post, farmer resource training institutions and others.

\section{CONCLUSION}

Implementation of agribusiness subsystem as an approach system of agricultural development and agribusiness planning at the level of feedlot farmer was in the not so good category, except farming subsystem was in the moderate category. Profit value of beef cattle farming with an average scale 2.95 head of cattle was smaller than the Provincial Minimum Wage of Central Java in 2010. The profit value was IDR 1,044,719 for 6.68 months, or equal to IDR 156,395 per month, whereas the minimum wage in the province of Central Java in 2010 was IDR 675,000. Subsystems implementation in the agribusiness system and agribusiness planning significantly influenced beef cattle farming profit simultaneously. Preproduction subsystems and agribusiness supporting service subsystem significantly influenced beef cattle farming profit partially, while farming subsystem, marketing, and agribusiness planning did not significantly influenced to beef cattle farming profit.

\section{REFERENCES}

Badan Litbang Pertanian. 2007. Teknologi Inovasi Pakan Murah Untuk Usaha pembibitan Sapi Potong. Pusat Penelitian dan Perngembangan Peternakan, Balitbang Pertanian, Departemen Pertanian. Jakarta.

Badan Pusat Statistik Provinsi Jawa Tengah. 2010. Jawa Tengah Dalam Angka 2009. Badan Pusat Statistik Provinsi Jawa Tengah. Semarang.

Dalton, C. 1987. An Introduction to Animal Breeding. English Language Book Society. Longmann.
Daniel, M. 2002. Metode Penelitian Sosial ekonomi. Penerbit Bumi Angkasa. Jakarta.

Hardjosubroto, W. 1994. Aplikasi Pemuliaan Ternak di Lapangan. PT. Gramedia Widiasarana Indonesia. Jakarta.

Legates, J.E., and E. J. Warwick. 1979. Breeding and Improvement of Farm Animal. Eight Edition. Mc Graw Hill Book Co, New York.

Lestari, C.M.S., R. Adiwinarti, M. Arifin and A. Purnomoadi. 2011. The performance of java and ongole crossbred bull under intensive feeding management. J. Indonesian Trop. Anim. Agric. 36(3): 109-113.

Prasetyo, E., T. Ekowati and Mukson. 2005. Kondisi dan potensi pengembangan usahatani ternak sapi perah di Kabupaten Semarang. Jurnal Pengembangan Peternakan Tropis. 30(2): 110-118.

Ramsey, R., D. Doye, C. Ward, J. McGrann, L. Falconer and S. Bevers. 2005. Factors affecting beef cow-herd costs, production andv profits. Journal of Agricultural Applied Economics. 37(1): 91-99.

Santosa, P.B. and Ashari. 2005. Analisis Statistik dengan Microsoft Excel dan SPSS. Penerbit Andi Offset. Yogyakarta.

Soeharjo, A. and D. Patong. 1973. Sendi-sendi Pokok Usahatani. Departemen Sosial Ekonomi Pertanian, Institut Pertanian Bogor. Bogor.

Sudarmono, A. S. and B. Sugeng. 2008. Sapi Potong : Pemeliharaan, Perbaikan Produksi, Prospek Bisnis, Analisis penggemukan. Penerbit Panebar Swadaya. Depok.

Supranto, J. 1984. Ekonometrik. Lembaga Penerbit Fakultas Ekonomi, Universitas Indonesia, Jakarta.

Van de Ven, G. W. J., N. De Ridder, H. Van Keulen and M. K. Van Ittersum. 2003. Concepts in production ecology for ananlysis and design of animal and plant-animal production system. Journal of Agricultural System. 76: 507-525. 